\title{
AUDIÊNCIAS PÚBLICAS NO STF: ESPAÇO DELIBERATIVO OU RETÓRICA?
}

\author{
Juliana Nobrega Feitosa \\ Tribunal de Justiça do Estado de São Paulo (TJSP), São \\ Paulo \\ jnobregaf@tjsp.jus.br
Silvia Carlos da Silva Pimentel
Pontifícia Universidade Católica de São Paulo (PUC-SP), São Paulo
spimentel@ pucsp.br

\begin{abstract}
RESUMO: Ao declarar que a República Federativa do Brasil se constitui num Estado Democrático de Direito, torna-se relevante o questionamento acerca da legitimidade democrática da tomada de decisões de quaisquer dos poderes estatais, inclusive do STF. Este trabalho utiliza como objeto de estudo o instrumento das audiências públicas, as quais foram institucionalizadas após a promulgação da $\mathrm{CF} / 88$. Por meio deste trabalho, verifica-se que, para além da legitimidade democrática dentro das cortes, as audiências exercem outro tipo de influência social. Assim, mesmo que as audiências não estejam, hoje, exercendo por completo as suas potencialidades, funcionam como uma caixa de ressonância de questões moralmente sensíveis. Contudo, desejável que o STF faça uso deste meio processual também para se estabelecer um diálogo com os diversos setores da sociedade, de modo a conferir racionalidade e legitimidade às suas decisões.
\end{abstract} PALAVRAS-CHAVE: Direito. STF. Democracia. Habermas. Audiências públicas.

\section{Public Hearings and STF: Is it a deliberative space or is it rhetoric?}

\begin{abstract}
In declaring that the Federative Republic of Brazil is a Democratic State of Law, it is relevant to question the democratic legitimacy of the decision-making of any of the state powers, including the Supreme Court. This paper uses as its object of study the instrument of public hearings, which were institutionalized after the promulgation of the $\mathrm{CF} / 88$. Through this work, it is verified that, besides the democratic legitimacy within the courts, the public hearings exercise another type. of social influence. So, if they aren't fully exercising their potential today, they act as a sounding board for morally sensitive issues. However, it is important that the Supreme Court makes use of this procedural mechanism also to establish a dialogue with the various sectors of society, in order to give rationality and legitimacy to its decisions.
\end{abstract}

KEYWORDS: Law. Supreme Court. Democracy. Habermas. Public Hearings.

\section{INTRODUÇÃO}

No contexto jurídico e político contemporâneo, os debates inserem-se em uma constante demanda por democratização das instituições, representação e formação de vontade popular. É bem verdade que o caráter representativo não se encerra exclusivamente pelo voto, uma vez que 
cabe ao Judiciário e, em especial, ao Supremo Tribunal Federal, assegurar a vontade do constituinte $^{1}$. Ademais, esta relação entre STF e democracia ganha contornos específicos, também em razão da própria Constituição, que o coloca como fiscal e protetor dos direitos humanos e da soberania.

Com efeito, diante dos acirrados debates em torno do funcionamento do poder judiciário na atualidade, e considerando-se que a República Federativa do Brasil se constitui num Estado Democrático de Direito, torna-se relevante o questionamento acerca da legitimidade democrática da tomada de decisões de quaisquer dos poderes estatais, inclusive do STF. Neste sentido, aduz José Rodrigo Rodriguez (2013, p.64):

\begin{abstract}
Ainda nesta parte, mostro como este processo, que denomino de luta pela justificação, tem gerado uma pressão crescente por mais transparência e acesso ao processo de tomada de decisões do Poder Judiciário, pressão essa que é amplificada pela crescente visibilidade deste poder na mídia nacional.
\end{abstract}

Desta forma, o objetivo deste estudo não se volta à análise da competência oferecida ao STF para exercer o controle de constitucionalidade das leis, mas sim direciona-se a avaliar se suas decisões, de fato, passam pelo manto da democraticidade. É que o papel da jurisdição constitucional e sua inserção democrática não se concebem sem o reconhecimento de que é necessário criar mecanismos de participação popular no processo de interpretação e aplicação da Constituição.

Este artigo tem como objeto de estudo o instrumento das audiências públicas, enquanto meio processual admitido pelas instituições e que viabiliza, em tese, o diálogo com diversos setores da sociedade, de modo a conferir maior racionalidade e legitimidade às decisões tomadas pela Suprema Corte. Pretende-se verificar se o referido mecanismo é capaz de aproximar a Corte da sociedade. Efetivamente. Ou seja, o presente trabalho buscará analisar em que medida as audiências públicas influenciam das decisões do Supremo Tribunal Federal.

Registre-se que o presente estudo parte da teoria do discurso de Jürgen Habermas, o qual enfrenta os debates acerca da legitimidade da jurisdição constitucional para, em seguida, contextualizar a inserção das audiências públicas e suas finalidades no procedimento de controle abstrato de constitucionalidade. Por fim, pretende verificar se referido instituto atua, de fato, como instrumento que reforça a atuação do STF, compatível com a teoria deliberativa de Habermas.

\title{
1. As CONTRIBUIÇÕES DE HABERMAS À TEORIA DEMOCRÁTICA
}

Em regra, busca-se conferir legitimidade democrática às Cortes Constitucionais por meio de três argumentos. O primeiro destaca que os juízes constitucionais também são representantes, porém não sob viés delegatário, mas sim como curadores. Ou seja, as cortes constitucionais possuem legitimidade democrática enquanto representantes da vontade da sociedade, inscrita nas normas constitucionais. O segundo argumento aduz que as cortes são uma instituição deliberativa e o terceiro remete a uma ampliação da participação, dando voz aos excluídos do processo eleitoral, contemplando a intervenção democrática.

\footnotetext{
1 Em “A razão sem voto: o Supremo Tribunal Federal e o governo da maioria”, Luís Roberto Barroso discute o tema e traz importante inovação aos debates, reconhecendo e legitimando o caráter representativo do Judiciário, ao lado de sua função contramajoritária. Trata-se da atuação do Judiciário, no âmbito do controle de constitucionalidade, como mecanismo de preservação de direitos fundamentais e proteção das minorias contra a vontade das maiorias eventuais. O termo contramajoritário, aliás, decorre da ideia de que o os membros do Judiciário não são eleitos pelo povo, ao contrário do que ocorre com os Poderes Executivo e Legislativo. (BARROSO, 2017).
} 
Em síntese, considera-se legítimo o exercício da atuação das Supremas Cortes conquanto suas decisões sejam baseadas em um processo deliberativo, participativo e enquadrado nas normas extraídas da Constituição. Desta feita, a base legitimadora do Direito contemporâneo não mais se esgota no poder de decidir (poder político), remetendo-se para a estrutura das decisões.

É a partir daí que a teoria habermasiana contribui para a análise e, quiçá, para a superação destas questões. É que o autor introduz um paradigma procedimentalista do Direito, fundamentado no princípio do discurso.

Daiane Nogueira de Lira (2012, p.64) sintetiza:

Na visão habermasiana, o Estado Democrático de Direito possui uma justificação
procedimental que torna compreensível a legitimidade do Direito a partir de proces-
sos e pressupostos comunicativos - que devem ser institucionalizados juridicamente
-, permitindo que os processos de criação e de aplicação do direito levem a resultados
racionais.

A abordagem da teoria de Habermas pode ser elencada em cinco pontos, de acordo com a didática de Ricardo Fabrino Mendonça (2016), a qual será utilizada neste artigo.

De saída, importa registrar que Habermas expõe uma teoria democrática normativa, alicerçada em uma concepção ampla de política, pela qual se defende a participação pública contínua para a tomada de decisões. Esta participação deve ser instituída por meio de formação de públicos, nos quais são discutidos problemas de interesse coletivo, fortalecendo a capacidade dos cidadãos de influenciar no processo decisório. Neste sentido, afirma Mendonça (2016, p.743) que

\begin{abstract}
Habermas não reduz a democracia a instituições políticas que possibilitem a grupos em competição buscar poder em condições de justiça. A democracia envolve um processo em que a soberania popular e o autogoverno são efetivamente exercidos. Dessa perspectiva, o sistema político precisa ser poroso à continuada participação cívica, que inclui ampla cadeia de atividades.
\end{abstract}

Um segundo ponto contributivo da teoria de Habermas funda-se em intercâmbios comunicativos, oferecendo uma abordagem discursiva, pela qual se reconhece o poder da linguagem enquanto modo poderoso de agência (ação comunicativa). Segundo Habermas, por meio da ação comunicativa, as dimensões de mundo podem ser transformadas, uma vez que a política é inseparável da linguagem. Não só isso, quando não existe um consenso imediato, a linguagem se traduz em processo dialógico, a fim de se chegar a um entendimento mútuo. Mais uma vez, Mendonça (2016, p. 746) sintetiza muito didaticamente:

Habermas adota um modelo discursivo de política, centrado na reflexividade coletiva
alimentada pelo diálogo público. Como argumentei, a política discursiva desenvol-
vida por Habermas permeia a construção dos selves, suas perspectivas, visões de
mundo e preferências. Isso ajuda a compreender por que democratas deliberativos se
opõem a modelos agregativos de democracia e recomendam o fortalecimento do de-
bate público.

A terceira contribuição da teoria habermasiana é no sentido da conexão entre discurso e razão. Para o autor, o confronto de opiniões conduz ao esclarecimento recíproco por meio de debates racionalizados. Assim, a esfera pública leva à racionalização da tomada de decisões, por meio do melhor argumento.

Um quarto ponto defende a ética do discurso e o pluralismo. A teoria de Habermas não parte do consenso. Ao contrário, o conflito tem papel central em suas ideias, o que demandaria, portanto, um procedimento para lidar com este confronto. Diante do pluralismo, o autor advoga um procedimento discursivo. Neste sentido, mais uma vez, Mendonça (2016, p.753) explica que: 
Audiências públicas no STF: espaço deliberativo ou retórica?

\begin{abstract}
Ao reconhecer o pluralismo - e o conflito -, Habermas deseja reconciliar a noção de autonomia privada e a noção de autonomia pública em uma teoria política que valoriza liberdades e singularidades individuais, mas que coloca o interesse público em seu núcleo. A passarela entre perspectivas particulares e interesses públicos - entre singularidades e coletividades - é o justo procedimento discursivo, que leva à construção de soluções mais complexas, para além da simples justificação das vitorias dos atores mais poderosos.
\end{abstract}

Por fim, como último ponto descritivo da teoria democrática de Habermas, pode-se citar a defesa de uma deliberação entre múltiplos públicos, ou seja, uma ideia fundada em uma discussão pública entre diferentes públicos, viabilizando a democracia deliberativa em sociedades complexas. E, por este viés, a sociedade civil atua como espaço público autônomo, distinguindose do sistema da ação econômica e da administração pública. Autônomo, porque distinto dos poderes institucionalizados, bem como do poder econômico, porém integrado. Porque ecoa a voz da soberania.

A normatividade desta proposta pode ser resumida, portanto, no seguinte sentido: se a deliberação e a participação são inevitáveis à legitimidade democrática, necessário aceitar-se um jogo de espaços públicos autônomos (minipúblicos) e as novas formas de institucionalidade que projetam, bem como estruturas formais que deverão ser testadas continuadamente.

Assim, por meio da teoria deliberativa, todos os afetados por uma decisão devem participar da prolação da mesma decisão. E o resultado da deliberação deve respeitar a igualdade e simetria, uma vez que todos devem ter lugar de fala.

Com efeito, de acordo com Mendonça (2016, p.756):

\begin{abstract}
Habermas desenvolveu essa ideia sobretudo por meio de seu modelo two-track, que enfatiza a necessidade de uma relação continuada entre instituições políticas e o poder comunicativo alimentado pela esfera pública. Uma esfera pública vívida é crucial, sendo que a vivacidade do debate público depende da existência de fluxos discursivos atravessando diferentes arenas.
\end{abstract}

Analisando os pressupostos da teoria de Habermas, verifica-se que a aceitação da decisão jurisdicional se funda na fundamentação racional e no debate público, uma vez que a esfera pública possui o caráter de legitimar e racionalizar as tomadas de decisão. É que a democracia deliberativa se estabelece no acordo, ou seja, no consenso quanto às razões utilizadas para a tomada de determinada decisão. Segundo o próprio autor (HABERMAS, 2003, p.347):

\begin{abstract}
Temos que livrar o conceito de política deliberativa de conotações de colocariam o tribunal constitucional sob pressão permanente. Ele não pode assumir o papel de um regente que entra no lugar de um sucessor de menor idade. Sob os olhares críticos de uma esfera pública jurídica politizada - da cidadania que se transforma na "comunidade dos intérpretes da constituição" -, o tribunal constitucional pode assumir, no melhor dos casos, o papel de um tutor.
\end{abstract}

Com efeito, é necessária a criação de instrumentos que possibilitem o debate público na esfera jurisdicional, ampliando os espaços de participação efetivamente argumentativos, de modo a garantir a legitimidade democrática do processo jurisdicional constitucional.

Neste sentido, é que a implementação do instituto da audiência pública pelo STF pode servir como instrumento democratizador das decisões do tribunal, o qual não possui a pré-aprovação democrática por meio do voto eleitoral. Assim, as audiências públicas surgiriam para solucionar duas questões problemáticas à interpretação constitucional. A primeira, de cunho técnico, tendo em vista que os juízes da Corte não têm nem deveriam ter conhecimento de todas as matérias levadas à discussão na arena jurídica. E a segunda, de teor político, a fim de sedimentar a legitimidade democrática de sua atuação e, por conseguinte, de suas decisões. 


\section{AUdiênCIAS PÚBLICAS E LEGITIMIDADE DEMOCRÁTICA}

O constitucionalismo contemporâneo exige novas formas de participação popular, não mais se contentado com o simples sistema eletivo e representativo cunhado pelo voto popular. Demanda-se novos instrumentos, capazes de ampliar o espaço público, a fim de que seja ultrapassada a cidadania formal, aperfeiçoando a democracia e a legitimidade dos poderes públicos.

Na sequência, a Constituição brasileira de 1988 revela esta tendência em vários dispositivos, não escapando de seu cuidado também o Poder Judiciário. Assim que, diante da relevância do exercício da jurisdição constitucional concentrada, notou-se a necessidade da institucionalização de procedimentos, no âmbito do STF, que alterassem o papel de mero espectador passivo dos cidadãos. Nas palavras de Daiane Nogueira de Lira (2012, p.73), quando do estudo da teoria discursiva habermasiana,

[...] era preciso conferir, nos termos da teoria de Habermas, um caráter dialógico ao processo constitucional, uma vez que os processos de entendimento dirigidos pela argumentação são os únicos capazes de fundamentar a aceitabilidade das decisões judiciais.

Assim, após dez anos da promulgação da Constituição Cidadã, emergem duas importantes inovações legislativas, quais sejam, as Leis $n^{\circ}$ 9.868/99 e $n^{\circ}$ 9.822/99, que tratam, respectivamente, acerca do processo e julgamento da ação direta de constitucionalidade e da ação declaratória de constitucionalidade, bem como sobre a arguição de descumprimento de preceito fundamental. As novidades trazidas pelo legislador cunharam-se na previsão expressa do amicus curiae e da realização de audiências públicas pelo Supremo Tribunal Federal.

Registre-se que apenas oito anos após a edição destas leis é que a primeira audiência pública foi realizada pelo STF, no ano de 2007, quando do processamento da ADI 3.510-DF, que discutia a constitucionalidade da chamada "Lei de Biossegurança". Nos últimos doze anos, portanto, consolidou-se o entendimento de que as audiências públicas exercem dupla função na prática decisória do STF. A primeira, relacionada à técnica, atesta que as audiências subsidiam os ministros com informações próprias do domínio científico, muitas vezes essenciais ao julgamento. A segunda, vinculada à prática democrática, emprega referido instituto como mecanismo de acesso e participação da sociedade civil na corte.

E, assim, neste ambiente, a audiência pública amplia os participantes do processo constitucional, a fim de que a sociedade organizada possa contribuir para a interpretação e aplicação do direito, retirando o monopólio ou, ao menos, minorando a tendência exclusivista centrada na figura do juiz. Neste sentido, aduz Lira (2012, p. 67) que:

\footnotetext{
Habermas rejeita a visão da Constituição como "ordem concreta de valores", da qual o Tribunal Constitucional seria um intérprete qualificado que se sobressai por suas supostas virtudes intelectuais e de acesso privilegiado à verdade, pois o juiz singular tem que conceber sua interpretação construtiva com um empreendimento comum, sustentado pela comunicação pública dos cidadãos. [...]

O pluralismo é um fato social e a legitimidade da jurisdição constitucional é garantida pelos pressupostos e procedimentos comunicativos que devem estar presentes no processo constitucional, inclusive garantido ampla dilação probatória e contraditório entre todos os interessados.
}

\subsection{As audiências públicas: breve análise prática}

Conforme retratado acima, o instituto da audiência pública foi consagrado como uma prática de abertura do Judiciário ao debate público e um mecanismo de reforço democrático 
Audiências públicas no STF: espaço deliberativo ou retórica?

(FRAGALE, 2015, p. 205). Compreender, contudo, a relação entre o instituto jurídico e a democracia, demanda dimensionar o real impacto da utilização deste instrumento no processo decisório

\title{
2.1.1. A legislação
}

No direito positivo, já são levantadas questões que podem restringir o pluralismo e a legitimidade conferida ao instrumento. É que os dispositivos legais (artigo $9^{\circ}, \S 1^{\circ}$ - para ADI- e artigo 20, $1^{\circ}$ - para ADC- não indicam que as audiências públicas sejam um espaço para ouvir manifestações de qualquer cidadão. Ao contrário, a lei demanda algum tipo de conhecimento específico.

Disso resulta a exclusão de outros indivíduos que, em que pese não busquem trazer informações técnicas, possam contribuir com experiências vivas e significativas, de modo a aproximar a técnica à realidade social, bem como concretizar a ideia de Peter Häberle sobre a sociedade aberta de intérpretes constitucionais. A restrição à expertise apenas mantém a elitização do tribunal, fechando-o à pluralidade que permeia a sociedade.

Karina Pinhão (2018, p.473) aduz, neste sentido, que:

\begin{abstract}
Dada esta limitação participativa, a priori e, ainda, o fato de o Relator que convocou a audiência possuir discricionariedade na escolha de quem poderá participar nesta, entende-se que seja necessário uma reforma legislativa no sentido de dispor sobre parâmetros mínimos que vinculem esta escolha. Tais parâmetros devem perquirir uma formação verossímil com a pluralidade existente na própria sociedade, sendo a mais heterogênea possível. Não se exclui, todavia, a necessidade de vinculação dos participantes com a temática em debate, o que, por outro lado, não significa a escolha exclusiva de especialistas como imposto pela literalidade desta lei.
\end{abstract}

É criticável, no que se refere à legislação que institucionaliza as audiências públicas, a livre disposição que goza o legislador para arquivar ou juntar aos autos do processo os trabalhos da audiência, uma vez que o relator pode optar por descartar todo o trabalho perpetrado. Mais ainda, ao relator cabe, de forma discricionária e com nenhum parâmetro de fato objetivo, convocar ou não a realização das audiências públicas e concentrar todo o julgamento em seu próprio arbítrio, ainda que se trate de questões de forte apelo ético e moral na sociedade.

Registre-se, portanto, que os filtros exercidos pelas regras processuais, bem como a decisão que não aceita intervenientes ou que os aceita, porém utilizando-se de determinadas seleções, são cruciais para o desenho do diálogo a ser travado na corte. Nesta perspectiva, Marta Machado e Ana Carolina Bracarense (2016, 687-688), quando da análise da ADPF n. 154, que envolvia a disputa acerca da interrupção da gravidez de fetos anencefálicos, atestam que:

(...) no caso do confronto judicial, há controvérsias específicas à participação - nem todos podem falar e isso depende de regras que definem a legitimidade ativa para propor ações, as decisões de aceitação de amicus curiae ou, como se deu no caso, a autorização para participar da audiência pública. (...)

A aceitação ou não do amicus curiae na causa, bem como a seleção daqueles que poderiam participar da audiência pública foi também objeto de disputa. Diversas organizações de movimentos sociais e membros da sociedade civil requereram a participação no processo como amicus curiae. Em um primeiro momento, o ministro Marco Aurélio negou os pedidos de participação. Entretanto, visto o significativo número de demandas por participação, no fim de agosto e início de setembro de 2008 , o STF decidiu promover uma Audiência Pública para que a sociedade civil se pronunciasse quanto ao tema. Após esta decisão, outras entidades manifestaram interesse em se pronunciar sobre o tema nessa esfera, o que foi negado pelo Relator, que 
se referiam ao fato de que já estavam participando do processo "os mais diversos segmentos da sociedade" ou de que a entidade requerente não suplementaria os elementos já expostos. Certamente essas decisões impactaram na conformação da disputa argumentativa que se deu na audiência pública.

De toda forma, ainda que a legislação possua arestas a serem aplainadas, os maiores debates, após doze anos da primeira convocação de audiência pública, concentram-se nos dados apresentados no âmbito dos processos nos quais foram utilizadas as referidas audiências.

E os números não são positivos.

\title{
2.1.2. Um balanço das audiências públicas
}

O trabalho realizado por Fernando Leal, Rachel Herdy e Júlia Massadas (2018) fornece detalhado panorama sobre o funcionamento real das audiências públicas no Supremo Tribunal Federal, o que permite ilustrar as disfuncionalidades gerais quando da utilização de referido instrumento nos últimos anos.

Segundo os autores (2018, p.367):

\begin{abstract}
O instituto, que parece ter sido concebido para suprir carências epistêmicas dos ministros, reduziu-se a um foro em que convivem, em pé de igualdade e sem critérios claros de diferenciação, opiniões desinformadas com posições de especialistas. Com isso, sobra desorientação para a justificação epistêmica das decisões. Ademais, como os dados apresentados revelam, não há na prática critérios para a convocação de audiências públicas e para a definição de quem está habilitado para delas participar, há baixos níveis de interação e confronto entre os participantes, presença reduzida de ministros, baixa incorporação das audiências nas decisões dos ministros e usos de falas dos participantes nos votos como indícios de confirmações de crenças ou hipóteses preexistentes, o que tende a revelar uso míope ou estratégico.
\end{abstract}

Ou seja, as audiências públicas, por meio dos dados levantados pela pesquisa, não demonstraram configurar-se, de fato, em instituto apto a conferir legitimidade democrática às cortes.

É que, de pronto, constatou-se que os participantes destas audiências eram, em sua grande maioria, peritos que levaram ao tribunal conhecimento especializado acerca de determinado assunto. Sem prejuízo da qualidade técnica que tais informações possam entregar às decisões judiciais, por si só, não se traduzem em debate dialógico e deliberação política. Ainda, havendo um alto número de técnicos envolvidos nas audiências, não ficou clara a heterogeneidade dos debates, o que gera um déficit representativo e um desequilíbrio quanto aos argumentos que poderiam ser alcançados.

Ainda, dado curioso denota que, na maioria dos despachos convocatórios das audiências públicas, há restrição quanto ao conteúdo das manifestações, no sentido de que seriam vedadas exposições de relatos pessoais. Ora, tais restrições podem afetar o senso democrático do diálogo justamente por não se aproximar da realidade social em que está inserida a questão em debate.

Não só isso, importa registrar que poucos são os ministros que, de fato, participam das audiências, quando não estão envolvidos com a relatoria da ação. De toda forma, em todos os casos, as transcrições das audiências foram disponibilizadas pelos relatores, mas não há clareza institucional acerca do acesso efetivo a elas pelos demais ministros. E é assim, porque os argumentos apresentados em audiência são muito pouco citados nos votos dos juízes e, quando o são, geralmente são utilizados como confirmação de uma ideia pré-concebida. 
Audiências públicas no STF: espaço deliberativo ou retórica?

Tendo tudo isso em vista, valiosa a relação entre o uso efetivo das audiências públicas e os ensinamentos de Habermas, construída por Karina Pinhão (2018, p. 477-478):

\begin{abstract}
Em resumo, apesar do importante potencial deliberativo das audiências públicas, estas acabam por se restringirem a uma visibilidade meramente de presença, mas não são capazes de tornarem presente e efetiva a participação dialógica, mais heterogênea, e inclusiva. A presença de múltiplas perspectivas culturais e sociais no debate político possui a vantagem de ampliar a qualidade epistêmica destes, mas não se pode deixar de considerar que, sem postular qualquer derivação mecânica ou determinista, ela não é capaz de conter a tendência para a reprodução das hierarquias e, assim, da dominação pelo discurso. Não significa que a audiência pública seja irrelevante e desprovida de importância, mas é preciso considerar em suas relações comunicativas ou dialógicas, as relações de força que nelas se efetivam sob uma forma transfigurada e como se revelam na aplicação de uma suposta racionalidade parcial. Por estas razões que se defende que as audiências públicas deveriam compor de forma mais significativa a decisão em sede de controle de constitucionalidade abstrato, desde que, ademais, respeitados estes procedimentos dialógico-comunicativos, ou seja, um agir comunicativo, como expressado por Habermas.
\end{abstract}

\title{
2.2. Para além da legitimidade democrática
}

De acordo com as pesquisas anteriormente mencionadas, verificou-se que, nos últimos anos, as audiências públicas não refletiram o resultado esperado nas decisões da corte. O que se notou é que elas, muitas vezes, foram instrumentalizadas como argumento de autoridade, a fim de validar não a pluralidade, e sim opiniões prévias dos ministros, sobretudo em razão da constatação de que as menções aos debates nos votos dos juízes quase sempre aparecerem de forma marginal.

É bem verdade que há aqueles estudos que enfatizam a necessidade de referido instituto, como método apto a implementar a democracia ou conferir caráter mais representativo aos tribunais constitucionais. Tem-se, por este viés, que a realização das audiências públicas pelo STF nos processos de aplicação e interpretação constitucional concretizam a teoria procedimentalista de Habermas, criando-se espaço de comunicação e participação e, ainda, conferindo caráter dialógico à jurisdição constitucional (LIRA, 2012, p. 78).

A crença e o otimismo, contudo, não sobrevivem a alguns outros estudos. O caráter democrático e a aproximação da corte com a sociedade, conforme muitas vezes argumentado pelos próprios ministros do STF, não parece comover a todos. Neste sentido, Carolina Vestena afirma (2010, p. 105):

Sendo assim, fica evidente a impossibilidade estrutural de que procedimentos de caráter formal, internos à cúpula do Judiciário, possam romper a lógica de reprodução das posições de poder no interior da formação social capitalista. Mesmo que sejam discursivamente defendidas como democráticas, as audiências públicas judiciais não ultrapassam a barreira da reprodução do formalismo intrínseco à atuação dos tribunais; pelo contrário, reproduzem-no com uma roupagem mais sofisticada. Com esses mecanismos, fica assegurada a manutenção das formas de controle e reprodução ampliada do capitalismo, que alcançam altos níveis de legitimidade por meio de práticas que pretensamente democratizam as instituições através da participação. Nesse contexto, a contra-leitura da democratização aqui desenvolvida explicita as reais relações de poder que moldam o corpo social, sob formação de falsos consensos e de participação em seu interior.

Ainda, na mesma análise cética em relação às audiências públicas, Leal, Herdy e Massadas asseveram que, em contraposição à legitimidade democrática, importa destacar a competência democrática, a qual tratar-se-ia de um valor constitucional que garante que as decisões em 
uma democracia possam ser tomadas de forma inteligente e racional, distinguindo-se o conhecimento especializado da mera opinião. Esta distinção implicaria na possibilidade de descriminar tanto conteúdo quanto os sujeitos da fala. E seria assim, porque a garantia da informação deve prevalecer aos direitos de expressão e de igualdade, pois teria por fundamento a construção sedimentada da capacidade cognitiva dos ministros. Para eles, portanto, direitos de expressão e igualdade devem ser restringidos, a fim de preservar a democracia. Em síntese, os autores concluem que (2018, p. 344-345):

O desenho de uma arena em que as pessoas com a mais variadas formações apresen-
tem ideias sobre questões de fato para os ministros do STF é estranho. Se o debate
científico é compatível com a pluralidade e saturação de ideias e experimentos, isso
não significa que qualquer visão sobre determinado assunto é cientificamente rele-
vante. No STF, há dois riscos permanentes. O primeiro é o de a solução de questões
envolvendo a valoração jurídica de aspectos da realidade eliminar ou determinar a
solução de questões de fato - e não o contrário. O segundo é o de disputas científicas
serem superadas com base em razões não científicas. O tribunal poderá, nessa linha,
não só basear decisões em meras opiniões, como abrir as portas para o chamado "lixo
científico!" (junk science): uma mistura de dados enviesados, inferências espúrias e
malabarismos lógicos costurados por pesquisadores cujos entusiamos pela desco-
berta e pelo diagnóstico ultrapassa em muito suas habilidades (...). Em qualquer dos
casos, como se nota, reunir mais informações não é necessariamente uma vantagem
para a justificação de decisões jurídicas.

É bem verdade que há descrença por boa parte da doutrina quanto à legitimidade democrática conferida à Corte Constitucional por meio das audiências públicas. Não só em termos teóricos, mas sobretudo em razão da praxe do Supremo quanto à instrumentalização deste instituto. De toda forma, não se pode olvidar que o mecanismo das audiências ultrapassa os limites da decisão a ser proferida.

Quando do processamento da ADPF n. 154, o Ministro Marco Aurélio descreve o caráter misto das audiências públicas, porquanto também judiciais. Desta forma, os trabalhos teriam o condão de convencer os juízes, bem como de conquistar a opinião pública. Ou seja, os argumentos utilizados são de diversas ordens e as repercussões dos debates suplantam a arena judicial.

Nesse sentido, ou seja, quanto à relevância das audiências que transcende a decisão judicial, cite-se Marta Machado e Ana Carolina Bracarense (2016, p. 685):

\begin{abstract}
Além disso, os efeitos da audiência pública não se restringem a seu grau de influência na decisão ou na formação de precedentes. Ela tem efeitos que transcendem a instituição judiciário. Consideramos essa arena aberta pelo judiciário um locus de visibilidade importante utilizado pelo movimento social para fazer ressoar no debate público suas posições (Kirchheimer, 1961; Barkan, 183). Dessa forma, o tribunal pode funcionar como palco - staging area, na expressão de Kirchheimer (1961:4) - para o confronto entre distintas posições. Trata-se de uma oportunidade para difundir argumentos, conquistar apoiadores e ampliar a adesão à causa.
\end{abstract}

Com efeito, em nosso entendimento, mesmo considerando interessantes e pertinentes muitas das críticas apresentadas, os diálogos travados em audiências públicas podem contribuir para a formação de uma decisão mais racional e para a construção de uma nova hermenêutica constitucional. Revelam-se, também, como espaço público não necessariamente dominado pela técnica, e, sim, configurado em arena de disputas éticas e morais, com forte apelo social. Ainda, por estarem estas disputas éticas e morais contextualizadas em um processo judicial, volvem-se em arena privilegiada, pois os participantes nelas investem seus argumentos, a fim de conquistar uma decisão favorável. Isto, de certa forma, sofistica o protagonismo judicial nas democracias contemporâneas. 


\section{APERFEIÇOAMENTO DAS AUDIÊNCIAS PÚBLICAS: ADPF 442 E A Ministra Relatora Rosa WebER}

Mais de vinte audiências públicas já foram realizadas no Supremo Tribunal Federal, as quais trataram de matérias diversas, que pendularam entre questões social e moralmente controversas, como quotas no ensino superior e aborto de fetos anencéfalos, e objetos mais técnicos, como importação de pneus usados e bloqueio do uso do whatsapp.

Conforme já retratado por este trabalho, a função exercida pelas audiências públicas ainda é controversa. Ora admitem que o instituto permite que se crie um campo deliberativo democrático, aproximando a sociedade civil e Judiciário; ora se entende que as audiências legitimam as decisões judiciais e ora se compreende que o mecanismo fornece subsídios técnicos aos ministros. Em verdade, as audiências acabam por representar um pouco de tudo isso.

Os dados empíricos, contudo, demonstram que os objetivos inicialmente buscados quando da institucionalização do instituto foram parcialmente frustrados, muito em razão da forma como foram arquitetadas pelos ministros relatores. De saída, pode-se afirmar que a presença esmagadora de peritos nestas audiências acaba por substituir a função dos peritos e desvencilhar-se das expectativas originárias, que seria justamente retratar o pluralismo social, trazendo-o para perto dos palcos judiciais. Ou seja, há pouca diversificação dos atores que frequentam a corte, afetando a democratização esperada. Ainda em relação aos participantes, constatase que a seleção realizada de forma unilateral pelos ministros relatores nem sempre contam com critérios objetivos, porquanto demasiadamente abertos e imprecisos.

Por conseguinte, o espaço público que deveria configurar-se em troca de argumentos, a fim de favorecer uma decisão justa e racional, estrutura-se em um quadro de contraditório, simplificando os debates, à revelia de posições intermediárias e ponderações.

Não só isso, verificou-se a ausência dos ministros nas audiências públicas, as quais, muitas vezes contavam apenas com a presença do ministro relator. Em que pese a disponibilização de vídeos no Youtube, bem como a disponibilização das transcrições dos debates, poucas vezes os argumentos foram mencionados nos votos dos ministros, o que acaba por revelar o pouco reconhecimento que é dado aos diversos atores participantes das audiências.

Todos estes elementos reunidos apontam que o instituto deve ser encarado com maior seriedade pelo Supremo Tribunal Federal, sob pena de configurar-se em retórica, apropriada pelos ministros quando da necessidade de legitimação de suas decisões.

De toda forma, merece atenção a audiência pública convocada pelo Ministra Rosa Weber em relação ao aborto voluntário (ADPF 442). É que a Ministra demonstrou sensibilidade e cuidado quanto à instrumentalização do mecanismo, trazendo inovações ao sistema, que podem contribuir ao aperfeiçoamento das audiências públicas e, quiçá, suprir algumas das deficiências já demonstradas por este e demais trabalhos.

Nesse sentido, vale a observação quanto ao despacho convocatório ${ }^{2}$ :

13. A discussão que ora se coloca para apreciação e deliberação desse Supremo Tribunal Federal, com efeito, é um dos temas jurídicos mais sensíveis e delicado, enquanto envolve razões de ordem ética, moral, religiosa, saúde pública e tutela de direitos fundamentais individuais. A experiência jurisdicional comparada demonstra essa realidade. Assim, a complexidade da controvérsia constitucional, bem como o

2 Disponível em: http://www.stf.jus.br/arquivo/cms/noticiaNoticiaStf/anexo/AudnciaPblicaADPF442.pdf. Acesso em: 25 de junho de 2019. 
papel de construtor da razão pública que legitima a atuação da jurisdição constitucional na tutela de direitos fundamentais, justifica a convocação de audiência pública, como técnica processual necessária, a teor do art. $6^{\circ}, \S 1^{\circ}$, da Lei n. 9.882/99, e dos arts. 13, XVII, e 154, III, parágrafo único, ambos do RISTF. 14. Os interessados deverão manifestar seu interesse em participar da audiência pública pelo endereço eletrônico adpf442@stf.jus.br até o dia 25 de abril de 2018. 15. A solicitação de participação deverá conter (i) a qualificação do órgão, entidade ou especialista, conforme o caso, (ii) a configuração do requisito da representatividade adequada, (iii) a indicação do expositor, acompanhada de breve currículo de até duas páginas, e (iv) o sumário das posições a serem defendidas na audiência pública. 16. Os participantes serão selecionados, entre outros, pelos seguintes critérios: (i) representatividade, especialização técnica e expertise do expositor ou da entidade interessada e (ii) garantia da pluralidade da composição da audiência e das perspectivas argumentativas a serem defendidas, como forma de se assegurar a legitimidade do processo de tomada de decisão e a utilidade dessa técnica processual para o esclarecimento de dúvidas acerca das diretivas e conteúdos interpretativos da matéria em debate. Ainda, como requisito à habilitação, os postulantes deverão apresentar justificativas que demonstrem capacidade técnica e/ou jurisdicional da sua contribuição para o diálogo sobre a questão. 17. A relação dos inscritos habilitados para participar da audiência pública, bem como a instrução do procedimento a ser seguido e perguntas prévias a serem respondidas será divulgada, mediante decisão monocrática irrecorrível, no portal eletrônico do Supremo Tribunal Federal.

Verifica-se, já pelo despacho da Ministra, que os critérios para a seleção dos participantes são claros e precisos e buscam oportunizar a todos o ingresso neste espaço, a fim de garantir a manifestação da diversidade, na busca de uma deliberação em que vários setores interessados manifestem suas vozes. Neste sentido, a Ministra Rosa Weber explica que o "volume de pedidos inviabiliza a admissão de todos. Os critérios para seleção adotados foram a representatividade técnica na área, atuação ou expertise especificamente na matéria e garantia de pluralidade e paridade da composição da audiência"3.

\section{Com efeito, a sensibilidade da Ministra não deixou de ser notada ${ }^{4}$ :}

O despacho convocatório, a lista de entidades e pessoas habilitadas e os demais documentos ligados à organização desta audiência pública dão indícios de que a ministra relatora da ADPF 442 busca criar um espaço amplo para a participação social e para a deliberação entre os vários setores interessados a se manifestar sobre a questão do aborto voluntário: movimento feminista, profissionais da área de saúde, setores vinculados à luta pelos direitos humanos, estudiosos e acadêmicos nacionais e internacionais, grupos religiosos, bem como instituições públicas ligadas à defesa de direitos.

Cite-se, ainda, como exemplo de inovação cunhado na ADPF 442, a construção de um espaço deliberativo após os debates, a fim de que os grupos, entidades e pessoas participantes pudessem formular e responder questões, favorecendo a troca de argumentos e razões, o que, certamente, vem para aprimorar o instituto constitucional.

Ou seja, em que pesem as críticas, há condições de reverter a aplicação meramente retórica das audiências públicas, quando e se houver interesse efetivo dos ministros envolvidos. Rosa Weber já mostrou o caminho.

\footnotetext{
${ }^{3}$ Disponível em: http://www.stf.jus.br/portal/cms/verNoticiaDetalhe.asp?idConteudo=380450. Acesso em: 25 de junho de 2019.

4 Disponível em: https://www.jota.info/opiniao-e-analise/artigos/audiencias-publicas-no-supremo-merecem-aperfeicoamento-e-inovacao-16072018. Acesso em: 25 de junho de 2019.
} 


\section{CONCLUSÃo}

As audiências públicas nascem e desenvolvem-se a partir de questionamentos acerca do caráter democrático dos tribunais. Tendo em vista que as cortes não contam com a legitimação do voto ou do mecanismo de accountability, os quais são impostos aos poderes Executivo e Legislativo, travam-se debates, a fim de fomentar e construir mecanismos capazes de incrementar a jurisdição constitucional.

Ao instrumento das audiências, portanto, investe-se o caráter de processo deliberativo, por meio do qual a participação social, nos palcos judiciais, levaria à troca de razões e argumentos necessários ao produto da deliberação, qual seja, a boa formação das decisões. Nesse sentido, o mecanismo estaria inserido no contexto teórico habermasiano, uma vez que a audiência pública criaria um espaço institucionalizado de comunicação e participação, adjudicando um estilo dialógico à jurisdição constitucional. Possibilitaria, ainda, a reunião de diversos elementos fáticos e científicos, de modo que o julgamento do processo se daria de maneira mais adequada e com maiores fundamentos. Nesse sentido, acerca dos ensinamentos de Habermas, aduz Karina Pinhão (2018, p. 470):

\footnotetext{
Para esta teoria, portanto, o método de discussão e decisão coletiva é a única forma de aceder à verdade moral e, somente o consenso real, formado a partir de um amplo debate com poucas exclusões, manipulações e desigualdade, é confiável para o acesso aos mandamentos morais. (...). Diante destes fatores, o agir comunicativo, à que se refere Habermas, compreende uma atividade argumentativa que exige dos membros a assunção das perspectivas uns dos outros e de todos.
}

Verificou-se, contudo, por meio de pesquisas empíricas acerca das audiências públicas já convocadas e realizadas pelo STF, conforme mencionado no subitem 2.1.2 deste trabalho, que o instituto ainda é desacreditado pelos próprios ministros da Corte, em que pese tenham se manifestado, todos eles, sobre a importância democrática do instituto. Suas análises comprovam que os debates atingem somente o ministro relator e que os argumentos levados na arena do Supremo praticamente não são utilizados pelos juízes. Esta falta de reconhecimento, assim, acaba por levantar críticas e ceticismos em relação ao mecanismo constitucional.

Pode-se, contudo, notar a mudança de postura do Supremo, ainda que tímida, cunhada em um movimento de inovação da Ministra Rosa Weber. Quando da convocação da audiência pública que trata sobre a interrupção da gravidez (ADPF 442), a ministra favoreceu a pluralidade de ingressantes, impediu repetição de argumentos e reconheceu o dever e a responsabilidade da Corte em levar os argumentos coletados em audiência para as suas decisões. Isto aponta para um sinal de transformação e aperfeiçoamento do instituto, que pode, então, levar a jurisdição constitucional a novos patamares dialógicos.

Assim, é evidente que as audiências emergem para aperfeiçoar o desenho institucional de democracia constitucional contemporânea. $\mathrm{O}$ instituto consagra a ideia de que a soberania do povo também pode fluir por espaços não majoritários, como é o caso do Supremo Tribunal Federal. É necessário, contudo, que os ministros consigam se abrir ao redimensionamento de suas funções num contexto de Estado Democrático de Direito. Paralelamente, importa que a sociedade também faça uso da cidadania de maneira substantiva, interessando-se pela prática dialógica, inclusive junto ao STF, por meio dos instrumentos disponibilizados, o que, consequentemente, levaria à implementação da participação civil em todos os espaços públicos. Esta dinâmica, de toda forma, já é notada, ainda que sutilmente. E é na insistência que a democracia se fortalece. 
Não obstante as dificuldades enfrentadas para a concretização do instituto, para além da legitimidade democrática dentro das cortes, as audiências exercem outro tipo de influência social, que não pode ser desprezada, pois também desenvolve a democracia. É que as audiências, mesmo que não estejam, hoje, exercendo todas as suas potencialidades, funcionam como uma caixa de ressonância de questões moralmente sensíveis. Os debates acabam por alcançar o público externo, ultrapassando os membros e as paredes da Corte, o que também colabora para a elaboração de outros espaços críticos e deliberativos. Ou seja, além de um papel político, há um aspecto simbólico importante. E a democracia também necessita de símbolos.

Esperamos que as audiências públicas representem um espaço deliberativo, resistindo à mera retórica. Esperamos que o instituto não se configure em artifício jurídico teatral. Afinal, o único espetáculo desejável, nesse palco, é o da racionalidade e da justiça.

\section{REFERÊNCIAS}

BARROSO, Luís Roberto. A razão sem voto: o Supremo Tribunal Federal e o governo da maioria. In: VIEIRA, Oscar Vilhena; GLEZER, Rubens (Org). A razão e o voto. Diálogos constitucionais com Luís Roberto Barroso. Rio de Janeiro: FGV Editora, 2017.

BRASIL. ADPF 442. Peças disponíveis em: http://www.stf.jus.br/arquivo/cms/noticiaNoticiaStf/anexo/AudnciaPblicaADPF442.pdf. Acesso em: 25 de junho de 2019.

BRASIL. ADPF 442. Notícia disponível em: http://www.stf.jus.br/portal/cms/verNoticiaDetalhe.asp?idConteudo=380450. Acesso em: 25 de junho de 2019.

FILHO, Roberto Fragale. Audiências públicas e seu impacto no processo decisório: A ADPF 54 como estudo de caso. Direito \& Práxis. Rio de Janeiro, v. 06, n. 12, 2015, p. 504-535.

GUIMARÃES, Lívia Gil. Audiências públicas no Supremo merecem aperfeiçoamento e inovação. JOTA: opinião e análise. Julho de 2018. Disponível em:http://www.jota.info/opiniao-eanalise/artigos/audiencias-publicas-no-supremo-merecem-perfeicoamento-e-inovacao-

16072018. Acesso em: 25 de junho de 2019.

LEAL, Fernando; HERDY, Rachel; MASSADAS, Júlia. Uma década de audiências públicas no Supremo Tribunal Federal (2007-2017). Revista de Investigações Constitucionais. Curitiba, v. 05, n.1, p. 331-372, jan/abr.2018.

LIRA, Daiane Nogueira. A audiência pública como instrumento de legitimação da jurisdição constitucional: uma análise a partir da teoria do discurso de Jürgen Habermas. Direito e Justiça, Ano 3, n. 32. 2012, p. 63-79

HABERMAS, Jürgen. Direito e Democracia: entre facticidade e validade. 2.ed. Trad. Flávio Beno Siebeneichler. Rio de Janeiro: Tempo Brasileiro, 2003, v. 1 e v. 2.

MACHADO, Marta Rodriguez de Assis; BRACARENSE, Ana Carolina. O caso do feto anencefálico: direitos sexuais e reprodutivos, confronto e negociação argumentativa no Supremo Tribunal Federal. Direito \& Práxis. Rio de Janeiro, v. 07, n.15, 2016, p. 677-714.

MENDONÇA, Ricardo Fabrino. Antes de Habermas, para além de Habermas: uma abordagem pragmatista da democracia deliberativa. Revista Sociedade e Estado. v. n, n. 3. Setembro/dezembro, 2016, p.741-768. 
Audiências públicas no STF: espaço deliberativo ou retórica?

PINHÃO, Karina Almeida Guimarães. A inserção das audiências públicas: reforço ou enfraquecimento da legitimidade democrática das decisões do Supremo Tribunal Federal? Revista Estudos Institucionais, v. 4, 1, 2018, p. 459-483.

RODRIGUEZ, José Rodrigo. Como decidem as cortes? Para uma crítica do direito (brasileiro). Rio de Janeiro: Editora FGV, 2013.

VESTENA, Carolina (2010). Participação ou formalismo? O impacto das audiências públicas no Supremo Tribunal Federal brasileiro (dissertação de mestrado). Rio de Janeiro: FGV, Mestrado Profissional em Poder Judiciário.

Recebido em: 28 jun. 2019.

Aceito em: 03 dez. 2019. 